\title{
AS IMPLICAÇÕES DA DECRETAÇÃO DA PRISÃO PREVENTIVA SOB A ÓTICA DA TEORIA DO GARANTISMO PENAL DE LUIGI FERRAJOLI
}

\author{
Luiz Fernando de Oliveira SOUZA ${ }^{1}$ \\ Mariane Silva PARÓDIA ${ }^{2}$ \\ Wagner Saraiva Ferreira Lemgruber BOECHAT ${ }^{3}$ \\ Malu Maria de Lourdes Mendes PEREIRA ${ }^{4}$
}

Recebido em: 05/10/2015 - Aprovado em: 02/12/2015 - Disponibilizado em: 18/01/2016

RESUMO: Busca-se com o presente trabalho a discussão acerca da teoria do garantismo penal criada por Luigi Ferrajoli e sua aplicação aos institutos penais, mais especificamente se tratando da prisão preventiva e sua decretação. O estudo se justifica pelo contínuo desrespeito às garantias constitucionais e à existência de inconstitucionalidades na própria lei. Assim aborda-se de modo sucinto a situação a tual do ordenamento jurídico quanto à proteção das garantias penais-constitucionais do indivíduo no processo penal. Enfatiza-se a ideia de um processo justo, garantista, e distante de qualquer tipo de inconstitucionalidade. Ressalta-se ainda a necessidade da utilização do Direito Penal como ultima ratio, mormente no que se refere ao processo cautelar. Isso com o fim de buscar-se levar o leitor a uma reflexão que vai ao encontro das garantias processuais cautelares e a sua aplicação à prisão preventiva, não deixando de observar os reflexos contemporâneos no ordenamento jurídico. A pesquisa tem cunho bibliográfico. Trata-se de artigo elaborado pelo Grupo de Estudos de Facetas dos Direitos Difusos e Coletivos.

PALAVRAS-CHAVE: Direito Penal. Garantias Penais. Prisão preventiva.

Artigo desenvolvido com apoio da FAPEMG através da concessão de bolsa de estudos.

\footnotetext{
${ }^{1}$ Bacharel do curso de graduação em Direito da Universidade Vale do Rio Verde - UninCor. E-mail: estudosdedireitoaplicado@gmail.com

${ }^{2}$ Advogada. Professora da Universidade Vale do Rio Verde - UninCor. Especialista em Direito Civil pela Universidade Anhanguera. E-mail: estudosdedireitoaplicado@gmail.com

${ }^{3}$ Advogado, consultor ambiental, professor de Direito na Universidade Vale do Rio Verde e Faculdade de São Lourenço. Graduado em Direito pela Faculdade de São Lourenço, pós-graduado em Direito Público pela Faculdade de São Lourenço, em Direito Tributário pela Fundação Getúlio Vargas, Direito Ambiental e Urbanístico pelo Centro Anhanguera de Promoção e Educação Social e mestre em Direito - linha Constitucionalismo e Democracia - pela Faculdade de Direito do Sul de Minas Gerais. E-mail: estudosdedireitoaplicado@gmail.com

${ }^{4}$ Auditora Fiscal da Receita Estadual (MG) e professora de Direito Administrativo e Direito Civil na Faculdade de Direito de São Lourenço/MG (UNISEPE). Graduada Direito e em Comunicação Social, pós-graduada e Mestre em Direito Constitucional pela Faculdade de Direito do Sul de Minas (FDSM). Também possui especializações em Direito Tributário, Direito do Estado, Direito Civil e Direito Notarial e Registral. É frequentadora dos cursos intensivos válidos para o doutorado em Direito Constitucional da Universidad de Buenos Aires, já tendo concluído os créditos. E-mail: estudosdedireitoaplicado@gmail.com 


\section{INTRODUÇÃO}

O presente artigo tem por escopo estudar a aplicação, desde o início do processo penal, mormente no que se refere à decretação da prisão preventiva, do garantismo penal; teoria que visa atuar na defesa das liberdades individuais do cidadão protegendo-o das ações arbitrárias do Estado através de um processo calcado nas garantias constitucionais, sobretudo na dignidade da pessoa humana.

Sabe-se que a prisão preventiva é estado provisório, excepcional e, ao menos teoricamente, medida cautelar legalmente válida. Entretanto, o problema aqui estudado, surge quando a decretação da prisão preventiva se torna regra, e não exceção. Juízes utilizam-se dessa medida como primeira opção, muitas vezes, furtando-se do dever de fundamentar a decisão que a decreta e, quando o fazem, recorrentemente, utilizam-se de fundamentos falaciosos e genéricos, conforme se verificará durante o texto.

A prisão parece ter virado regra. Prende-se para depois averiguar, volta-se aos primórdios onde não existiam garantias.

Ademais, o próprio Código de Processo Penal traz em seu conteúdo os fundamentos para a decretação da prisão preventiva, mostrando-se falho e inclusive inconstitucional no que pertine às utilizações dos fundamentos de garantia da ordem pública e garantia da ordem econômica.

Assim o presente estudo se justifica duplamente, pois ataca problema prático da vida cotidiana forense e por outro lado age como fomentador e correções na própria teoria do direito penal.

Muito embora a teoria não seja nova, verifica-se que os operadores do Direito, corriqueiramente, não tem utilizado sequer os fundamentos mínimos da teoria do garantismo penal para tutelar a liberdade, o segundo bem penal mais relevante constitucionalmente. Motivo esse pelo qual, além de apresentar críticas e propostas ao anteriormente explanado, o presente artigo tem como objetivo ainda manter a chama da discussão sobre as reformas legislativa e de aplicação fática da lei penal.

Para tal, uma vez que o diagnostico do problema na sociedade é claro, parte-se para uma pesquisa bibliográfica em acervos próprio e da Universidade Vale do Rio Verde e emprega-se o método hipotético dedutivo. 
Este artigo foi elaborado por estudantes e pesquisadores do Grupo de Estudos Facetas dos Direitos Difusos E Coletivos, que visa congregar preferencialmente pesquisas de cunho teórico, bibliográfico e com o método hipotético dedutivo que se dirijam aos ramos dos Direitos coletivos e difusos; bem como estudar as interações jurídicas formadas a partir de diplomas jurídicos que estatuem direitos a princípio individuais, mas que, devido às interações do sistema jurídico ou da sociedade, apresentam reflexos difusos ou coletivos.

\section{DO GARANTISMO PENAL}

Em virtude de sistemas extremamente punitivos em regimes antigos, sem medo de punições, sem receios quanto às condenações, arbitrário e abusivos em decisões, Beccaria, Voltairee e Filangieri, na obra de Filangieri (2003, p. 119) discutem uma reforma penal a retirar "ao inocente todo medo, ao infrator toda esperança, e aos juízes todo arbítrio".

Codificação legislativa do direito penal, humanização e racionalização do sistema das penas, secularização e liberalização dos delitos, demolição dos institutos do processo inquisitório e introdução das garantias fundamentais do imputado: de acordo com Ippolito (2008, p. 320) são estes os objetivos dos iluministas.

Nesse contexto, surgem as perguntas que induzem o problema penal: quando proibir? Como punir? Como julgar?

Baseado em pressupostos iluministas e sempre tendo como base os juristas acima, criada por Luigi Ferrajoli a partir do final da década de 80 , com a publicação da obra Direito e Razão - a teoria do garantismo penal possui caráter contemporâneo, até mesmo de acordo com Ferrajoli em uma entrevista concedida a Gerardo Pisarello e Ramón Suriano, na Universidad Carlo III de Madrid, em 1997:
La palabra garantismo es nueva en el léxico jurídico. Fue introducida en Italia en los años 70 en el ámbito del Derecho Penal. Sin embargo, creo que puede extenderse a todo el sistema de garantías de los derechos fundamentales. En este sentido, el garantismo es sinónimo de Estado constitucional de Derecho (1998, pp. 187-192)

Essa teoria defende a ideia de que um estado de direito deve assegurar aos indivíduos um modelo garantista do direito penal, que proteja efetivamente, em 
primeiro lugar, os direitos de liberdade, e em segundo lugar, os direitos sociais.

Consequência deste modelo garantista, surge um juspositivismo crítico contraposto a um juspositivismo dogmático, criando um Estado sob um alicerce de Direitos fundamentais.

Consoante Cademartori (1999, p. 161), a proposta garantista sugere, "um Estado minimizador das restrições das liberdades dos cidadãos dentro de um Estado Social maximizador das expectativas sociais, com correlatos deveres, do próprio Estado, de satisfazer tais necessidades".

Bobbio (2014) afirma que a teoria do garantismo penal tem por fundamento e por escopo a tutela da liberdade do indivíduo contra as várias formas de exercício arbitrário do poder, particularmente odioso no direito penal.

Trata-se de uma antítese que atravessa a história da civilização entre liberdade e poder.

O garantismo inicia-se através do princípio da legalidade, mas isto não faz com que legalidade e legitimidade se identifiquem. Aqui, há uma junção entre os dois conceitos, assim como entre vigência e validade, pois esta subordina a norma aos 'valores materiais' expostos na
Constituição. Assim, não há presunção de que os atos estatais são sempre regulares, até porque não é suficiente o respeito ao formalismo legislativo para que seja possível afirmar que uma norma seja válida.

O garantismo tem por escopo criar limites ao exercício arbitrário do poder de punir, com o objetivo de garantir os direitos fundamentais do réu, tendo em vista principalmente os direitos individuais. Há uma busca pela racionalização do poder de punir, tendo como principal garantia as garantias fundamentais previstas na Constituição, mas, principalmente, a liberdade.

Percebe-se que não se trata apenas de uma teoria que defende a batalha por direitos fundamentais, mas uma teoria que defende e transforma a batalha pelas minorias, oprimidas por um sistema que as menospreza.

Ferrajoli (2001) não sugere a alteração da estrutura do Estado, mas tãosomente, o aperfeiçoamento do Estado de direito que vige em determinado lugar, ou seja, a estrutura política base, nascente.

Passados mais de vinte anos da criação da teoria, há, ainda, depreciação e rotulação por parte dos jurídicos conservadores acerca da teoria, tendo em 
vista a sua obra, Direito e Razão, tratar da (in)efetividade das liberdades e garantias dos cidadãos.

Carvalho (2008), tendo por orientação a teoria de Ferrajoli, afirma que o problema da legitimidade política e moral do direito penal como técnica de controle social mediante constrições da liberdade dos cidadãos é, em boa parte, o próprio problema da legitimidade do Estado como monopólio organizado pela força.

É importante ressaltar que embora Ferrajoli tenha baseado a Teoria do Garantismo Penal sob à ótica do direito penal mínimo, em nenhum momento ele sugere a extinção de um sistema penal, ou sequer sua deslegitimação, mas sim justificar e limitar a intervenção penal a critérios realmente necessários.

Zaffaroni (2001, p. 95) afirma:

Para este autor [Luigi Ferrajoli], a deslegitimação do sistema penal não corresponde à idéia que tem sido exposta aqui, ou seja, à irracionalidade de nossos sistemas penais vigentes e operantes, mas sim à impossibilidade radical de legitimar qualquer sistema penal, inclusive futuro e mínimo que seja. Ferrajoli recusa esta radicalização, que parece identificar como própria do abolicionismo, afirmando que mesmo em uma sociedade mais democratizada e igualitária, seria necessário um direito penal mínimo como único meio de serem evitados danos maiores (a vingança ilimitada).

\section{O GARANTISMO PENAL E A PRESUNÇÃO DE INOCÊNCIA}

Ferrajoli afirma que a presunção da inocência equivale à presunção de falsidade de uma tese não provada. Explica que o ônus da prova sob responsabilidade da acusação é o ônus de produzir confirmações empíricas da hipótese acusatória idôneas para sufragar a sua aceitação como verdade; o contraditório com paridade das partes antagonistas representa a colocação à prova da hipótese de acusação através da sua exposição às confutações e às contraprovas produzidas pela defesa; atuação como terceiro e a independência do juiz ${ }^{5}$, a oralidade e a publicidade do procedimento, o dever de motivação das sentenças e o direito ao recurso são as regras que asseguram a correção do juízo e a possibilidade de um controle sobre esse. No seu complexo, estas garantias compõem o modelo

\footnotetext{
${ }^{5}$ Analogicamente com as explanações de Ferrajoli, é necessário entender "independência", aqui, não como forma de atuação ex officio e liberdade ampla no processo penal, mas sim como forma de atuação independente de elementos externos acusatórios que sejam estranhos e prejudiciais ao réu e ao processo penal garantista.
} 
cognitivo do processo penal orientado à procura da verdade e tendem, portanto, a proteger o inocente de punições injustas.

\section{DIREITO PENAL MÍNIMO}

$\mathrm{O}$ direito penal deve ser utilizado minimamente, tendo em vista que sua prática implica à violação do direito de liberdade do ser humano.

Dessa forma, a concretização de direitos deve ser atingida por meio de políticas sociais que efetivamente possuam eficácia. Contudo, quando estas mostrarem-se insuficientes, restando ao direito o dever de solucionar as lides que possam surgir, deve o direito penal ser utilizado de maneira a homenagear a liberdade individual, um dos valores do Estado Democrático de Direito.

Todavia, há um anseio social criado pela massa conservadora para que o direito penal seja baseado na supressão de garantias, como forma de redução da criminalidade, apontando-se para uma fórmula ilógica de ação e reação.

Neste contexto, quanto mais excessivo for a atuação penal, menor serão os índices de criminalidade. Resumidamente, busca-se garantir direitos humanos com a eliminação de direitos humanos. Porém, o que se percebe é inoperância do sistema para tanto, pois a atuação legislativa (principalmente no Brasil) culmina em leis penais inconstitucionais, que ofendem os objetivos de igualdade (com) prometidos pelo Estado Democrático de Direito, facilitando e permitindo atuações arbitrárias, possibilidade de atuação ex officio na aplicação de medidas e (super)valorização de opinião pública.

\section{DA PRISÃO PREVENTIVA}

Reza o artigo $5^{\circ}$ da Constituição Federal em seu inciso LVII, "Ninguém será considerado culpado até o trânsito em julgado de sentença penal condenatória". Consequência de tal artigo, o réu é presumidamente inocente até que transite em julgado a sentença condenatória. Consagrando-se, deste modo, um dos princípios basilares do Estado Democrático de Direito como garantia processual penal, com fins de tutela da liberdade pessoal.

Por óbvio, mesmo o artigo supracitado sendo considerado aquele que garante a presunção de inocência, não revoga e não tem o poder de determinar a revogação as prisões cautelares. 
As prisões são constitucionalmente permitidas, conforme o artigo $5^{\circ}$, inciso LXI da Constituição Federal.

A prisão preventiva, especificamente, é uma espécie de medida cautelar decretada pela autoridade judiciária competente, mediante representação da autoridade policial ou requerimento do Ministério Público, do querelante ou do assistente, em qualquer fase das investigações ou do processo criminal (nesta última, pode ser decretada de ofício pelo juiz), sempre que estiverem presentes os requisitos legais (artigo 313 do Código de Processo Penal) e ocorrerem os motivos autorizadores presentes no artigo 312 do CPP e, logicamente, desde que sejam inadequadas ou insuficientes as medidas cautelares expostas no artigo 319 do CPP.

Todavia, conforme a norma insculpida no artigo 282 do Código de Processo Penal, a prisão preventiva é medida extrema, que só deverá ser decretada quando não for cabível a sua substituição por outra medida cautelar prevista no código de processo penal que seja capaz de garantir a cautelaridade.

Noutro giro, é de sabença que o direito penal representa ramo do Direito de ultima ratio, o que significa dizer que só deverá ser invocado em favor dos bens jurídicos imprescindíveis à coexistência pacífica das pessoas e os quais não possam ser suficientemente protegidos de forma menos gravosa, ou seja, desde que não seja possível a plena solução do problema concreto por outro ramo do direito. Tal é a ideia contida no princípio da intervenção mínima ou princípio da fragmentariedade.

A este respeito vale mencionar exposição de Grecco (2006, p. 65):

O caráter fragmentário do
Direito Penal significa, em
síntese, que uma vez
escolhidos aqueles bens
fundamentais, comprovada a
lesividade e a inadequação das
condutas que os ofendem,
esses bens passarão a fazer
parte de uma pequena parcela
que é protegida pelo Direito
Penal, originando-se, assim, a
sua fragmentariedade.

Nesta senda, face ao princípio da fragmentariedade e, ainda, considerando a excepcionalidade do estado de prisão, impõe-se que a decisão que decreta a prisão preventiva seja prolatada por um julgador imparcial e, além disso, um Magistrado de garantias, tal é a ideia contida na teoria do garantismo penal.

Nesse diapasão, mister se faz inserir o caráter da pena privativa de liberdade, especificamente da prisão preventiva, no contexto garantista, pois 
conforme preleciona Beccaria (2008), não

há liberdade quando algumas vezes permitem as leis que em certos acontecimentos o homem deixe de ser pessoa e se considere coisa.

$$
\text { Isso significa que }
$$

independentemente de qualquer argumento que possa haver, impõe-se em favor do indivíduo uma limitação fundamental em relação a quando decretar a prisão preventiva $^{6}$. Ainda que o pensamento de Baccaria refletisse a sociedade iluminista, cediço é que o mesmo permanece atual.

Dessa forma, parece haver um pensamento institucionalizado de que é necessário encarcerar todo aquele que comete delitos, pois, a não-prisão demonstra-se como omissão do estado, pensamento este difundido mormente pelos meios de comunicação alheios a legislação vigente.

A prisão preventiva decretada antes da sentença condenatória não deve ter o caráter educativo e sequer repressivo, sob pena de ofender a própria natureza jurídica da prisão preventiva, que é medida cautelar.

\footnotetext{
${ }^{6}$ Ferrajoli (2014, p. 64), afirma que é este o valor sobre o qual se funda irredutivelmente, o rechaço da pena de morte, das penas corporais, das penas infames e, por outro lado, da prisão perpétua e das penas privativas de liberdade excessivamente extensas.
}

Entendendo o julgador em decretar a prisão preventiva do réu, deve utilizá-la de modo que não perverta o réu, que não seja desproporcional ao delito cometido, e que se adeque aos fundamentos autorizadores da prisão preventiva ${ }^{7}$.

A pena deve ser proporcional à gravidade do delito, sempre aliada à ideia de gravidade versus fundamento, ou seja, a prisão preventiva deve se ater à gravidade do delito, atendendo os fundamentos que a autorizam, tendo-se sempre em voga o resguardo de liberdades

O modelo garantista no contexto da prisão preventiva, que é cautelar, caracteriza-se por dez restrições ao arbítrio legislativo ou erro judicial:

\begin{abstract}
Segundo este modelo, não se admite nenhuma irrogação de pena sem que se tenha sido cometido um fato, previsto legalmente como crime, de necessária proibição e punição, gerador de efeitos danosos a terceiros, caracterizado pela exterioridade e materialidade da ação, pela imputabilidade e culpabilidade do autor e, além disso, comprovado empiricamente por acusação diante de um juiz imparcial,
\end{abstract}

\footnotetext{
${ }^{7}$ Platão, em Le leggi, (IX, 857b, p. 62-363) afirma: "Não temos que distinguir entre o ladrão que rouba muito ou pouco, ou que rouba de lugares sagrados ou profanos, nem adentremos a tantas outras circunstâncias inteiramente dessemelhantes entre si, como se dão nos roubos que, sendo variados, exigem que o legislador se atenha a elas impondo castigos totalmente diferentes?"
} 
em processo público realizado em contraditório, mediante procedimentos préestabelecidos em lei (Ferrajoli apud Maia, 2000).

Em atenção aos ensinamentos de Ferrajoli (2006, p. 508):

[...] para Hobbes, a prisão preventiva não é uma pena, mas um 'ato de hostilidade' contra o cidadão, de modo que 'qualquer dano que faça um homem sofrer, com prisão ou constrição antes que sua causa seja ouvida, além ou acima do necessário para assegurar sua custódia, é contrário à lei da natureza'. Para Beccaria, 'sendo a privação da liberdade uma pena, não pode preceder a sentença senão quando assim exigir a necessidade': precisamente, a 'custódia de um cidadão até que seja julgado culpado,... deve durar o menor tempo e deve ser o menos dura possível' e 'não pode ser senão o necessário para impedir a fuga ou não ocultar a prova do crime'. Para Voltaire, 'o modo pelo qual em muitos Estados se prende cautelarmente um homem assemelha-se muito a um assalto de bandidos'. Analogamente, Diderot, Filangieri, Condorcet, Pagano, Bentham, Constant, Lauzé di Peret e Carrara denunciam com força a 'atrocidade', a 'barbárie', a 'injustiça' e a 'imoralidade' da prisão preventiva, exigindo sua limitação, tanto na duração como nos pressupostos, aos casos de 'estrita necessidade' do processo.

O grande problema da prisão preventiva iniciou-se com o advento do fascismo, quando o princípio da presunção de inocência foi mitigado, sendo a prisão utilizada como medida de segurança social, perdendo o seu caráter fragmentário.

De acordo com a teoria do garantismo penal, a prisão preventiva assumia assim a fisionomia de uma verdadeira medida de prevenção contra os perigosos e suspeitos ou, de uma execução provisória, ou antecipada, da pena. E terminava por alterar a ordem completa do processo e, mais em geral, do sistema penal. O elemento mais dilacerante e aberrante foi indubitavelmente aquela invenção fascista da obrigatoriedade da prisão (provisória).

$\mathrm{O}$ ordenamento jurídico penal por si só já é carregado de situações desproporcionais ao acusado, e a prisão preventiva e sua decretação não pode possuir caráter arbitrário e sequer discricionário.

\subsection{PROVISIORIEDADE}

A provisoriedade está diretamente ligada ao tempo que a prisão deve(ria) ser mantida, tendo em vista que demonstra uma situação provisória, não podendo assumir um caráter de prisão pena. 
Porém, há um grande problema: até quando o cidadão ficará preso? Não há tempo determinado. A prisão preventiva deve possuir o caráter provisório, até o juiz ou tribunal entender que não existe mais nenhuma forma de perigo decorrente do estado de liberdade do acusado.

A Lei n. 11.719/2008 estabeleceu que no rito comum ordinário a audiência de instrução e julgamento deve ser realizada em, no máximo, 60 dias. Estabeleceu ainda que no rito sumário o prazo será de 30 dias. No rito do Tribunal do Júri, foi fixado o prazo de 90 dias para o encerramento da primeira fase.

Esses marcos podem ser utilizados como apontamentos de excesso de prazo em relação à prisão preventiva. Porém, como não há nenhum tipo de sanção, se mostram ineficazes, pois a situação que se vê é o descumprimento desses prazos processuais, até mesmo pela falta de estrutura judiciária no país.

Assim, grandes abusos são realizados dia após dia, sendo exemplo disso o julgamento RHC 20.566/BA, Rel. Min. Maria Thereza De Assis Moura, julgado em $12 / 06 / 2007^{8}$, que foi solucionado pelo STJ.

${ }^{8}$ RHC. PRISÃO PREVENTIVA. SÚMULA N. 52-STJ. A Turma deu provimento ao recurso em habeas corpus para que o
Porém, mesmo tendo havido uma nova interpretação da absurda súmula $52^{9}$ do STJ, ela continua a ser aplicada no país, que segundo Badaró (2006,), cria um termo final anterior à prolação da sentença que é incompatível com o direito fundamental de ser julgado em um prazo razoável, fixado no art. 5, LXXVIII, da Constituição.

\subsection{EXCEPCIONALIDADE}

No Brasil, tem-se a sensação que a prisão preventiva está sendo banalizada, e muitas vezes é decretada sem ser justificada, sequer fundamentada. Verificase que para muitos julgadores uma regra é certa: primeiro se prende, e em seguida encontra-se um suporte probatório para legitimação da medida, quando na verdade deveria ser o contrário, primeiro deve-se

recorrente, preso há mais de três anos, aguarde em liberdade o julgamento do processo mediante o compromisso de comparecer a todos os atos do processo para os quais for chamado. Isso no entendimento de que, ainda que encerrada a instrução, é possível reconhecer o excesso de prazo diante da garantia da razoável duração do processo, prevista no art. $5^{\circ}$, LXXVIII, da CF/1988, com a reinterpretação da Súmula n. 52-STJ à luz da EC 45/2004.

9 Súmula n. 52: "Encerrada a instrução criminal, fica superada a alegação de constrangimento ilegal por excesso de prazo". 
investigar, para depois encarcerar, caso haja fundamento autorizador para tanto.

Com total razão, Ferrajoli afirma que a prisão cautelar é uma pena processual, em que primeiro se castiga e depois se processa, atuando com caráter de prevenção geral e especial e retribuição.

A prisão preventiva não deve ter natureza punitiva, mas o que se vê é a sua utilização distante de sua natureza jurídica cautelar. Exemplo disso é a sua forma de cumprimento, que é até mesmo pior que forma de cumprimento de uma prisão penal. Deveria a prisão preventiva ser cumprida em instituições penais especiais, com suficientes comodidades, e não como é hoje, em que o preso cautelar está em situação pior do que a do preso definitivo (pois não possui direito ao regime semiaberto ou saídas temporárias).

De acordo com Carnelutti (1950, p.

As exigências do processo penal são de tal natureza que induzem a colocar o imputado em uma situação absolutamente análoga ao de condenado. É necessário algo mais para advertir que a prisão do imputado, junto com sua submissão, tem, sem embargo, um elevado custo? $\mathrm{O}$ custo se paga, desgraçadamente em moeda justiça, quando o imputado, em lugar de culpado, é inocente, e já sofreu, como inocente, uma medida análoga à pena; não se esqueça de que, se a prisão ajuda a impedir que o imputado realize manobras desonestas para criar falsas provas ou para destruir provas verdadeiras, mais de uma vez prejudica a justiça, porque, ao contrário, lhe impossibilita de buscar e de proporcionar provas úteis para que o juiz conheça a verdade. A prisão preventiva do imputado se assemelha a um daqueles remédios heroicos que devem ser ministrados pelo médico com suma prudência, porque podem curar o enfermo, mas também pode ocasionar-lhe um mal mais grave; quiçá uma comparação eficaz se possa fazer com a anestesia, e sobretudo com a anestesia geral, a qual é um meio indispensável para o cirurgião, mas ah se este abusa dela!.

Lopes (2014) leciona que a ditadura da urgência é terreno fértil para discussões superficiais, reducionistas e soluções epidérmicas e sedantes.

Dessa forma, as prisões preventivas acabaram sendo inseridas na dinâmica de urgência. Tal afirmação é exatamente a demonstração de como ela é manejada no país atualmente, pois quando se prende, cria-se uma falsa sensação de que houve justiça e que o judiciário é eficiente em relação à matéria penal.

Dessa forma, a prisão preventiva, que era para ser medida extrema, carregada de preservação de garantias, transforma-se em medida genérica, decretada a todo e 
qualquer instante, sendo um problema não só legislativo, mas cultural e político.

\section{COMO PRENDER?}

A prisão preventiva pode ser decretada durante a investigação criminal ou durante o processo, inclusive após a sentença condenatória recorrível, em decisão fundamentada, mediante requerimento do Ministério Público ou representação da autoridade judicial.

Além disso, o legislador introduziu a possibilidade da decretação da prisão preventiva de ofício pelo Juiz, desde que seja decretada no curso da ação penal.

Dessa forma, há de existir prova da existência do crime, e o perigo que decorre do estado de liberdade em que se encontra o sujeito.

\subsection{FUMUS COMISSI DELICTI}

O fumus comissi delicti é o requisito para decretação da prisão preventiva, pois deve haver prova da existência do crime e indícios suficientes de autoria.

Em relação aos indícios suficientes de autoria, é necessário que seja feito um juízo de probabilidade, tendo em vista que se tratando de medida cautelar, não há que se falar em juízo de certeza.

Segundo Carnelutti (1950), a probabilidade é vista como um predomínio de razões positivas sobre a qual a infração penal é analisada.

Dessa forma, requisitos positivos do crime significam a prova de que a conduta é, aparentemente, típica, ilícita e culpável. Da mesma forma, não podem existir requisitos negativos do delito. Não podem existir causas de exclusão de ilicitude ou exclusão de culpabilidade.

Não deve se esquecer, além do que foi exposto, da análise do elemento subjetivo do tipo, pois a verificação do dolo pode causar a atipicidade da conduta, fator que evitará a decretação de qualquer medida cautelar eventualmente sugerida.

Para sintetizar, é necessário que o Juiz verifique a conduta humana voluntária e dirigida a um determinado fim, um resultado, um nexo causal e a tipicidade, mormente a material.

Mesmo analisando a tipicidade, por si só ela não é suficiente para tal análise, pois de maneira formal, o crime exige a prática de um ato que além de típico, deve ser ilícito e culpável, de forma aparente. 
Por fim, é indispensável que haja um mínimo de provas suficientes, no sentido de demonstrarem a autoria e materialidade, além da imprescindibilidade da fundamentação da decisão.

O problema é que esse conceito, extraído do artigo 312 do CPP, pode levar a inúmeras interpretações, fugindo da interpretação garantista que deveria possuir.

Lopes (2014) afirma que a fumaça da existência de um crime não significa juízo de certeza, mas de probabilidade razoável.

Ainda segundo o mesmo autor supra citado, o fumus comissi delicti traz consigo a existência de indícios, com suporte probatório mínimo real, retiradas de reais investigações, que desprendidas de qualquer interferência política ou midiática, possa presumir que houve um delito, que foi realizado por um sujeito concreto.

O pedido da prisão preventiva deve vir acompanhado de provas suficientes que demonstrem a suposta autoria e a materialidade da infração, devendo o juiz fundamentá-la de forma não genérica ao decretá-la.

\subsection{PERICULUM LIBERTATIS}

Periculum Libertatis é o perigo decorrente da liberdade do sujeito, que traz, de acordo com o CPP, risco para a ordem pública, ordem econômica, conveniência da instrução criminal ou para assegurar a aplicação da lei penal.

Távora (2014) define o periculum libertatis como sendo o risco provocado pela manutenção da liberdade do sujeito passivo da persecução penal.

Pode se dizer que, ao verificar o cabimento de uma prisão preventiva, o magistrado deve verificar o tipo penal atribuído à prática, aferindo, a partir do art. 313 do CPP, se o crime em questão admite a decretação da prisão preventiva. Em seguida, incumbe ao Juiz analisar se há elementos que apontem no sentido da presença da existência do crime e indícios suficientes de autoria (fumus comissi delicti, analisado anteriormente). Por fim, deve-se aferir a presença do periculum libertatis, aqui entendido como o perigo concreto que a permanência do sujeito em liberdade acarreta para a investigação criminal e para o processo penal.

O fator problemático na análise do periculum libertatis é a ampla liberdade do juiz concedida pelo CPP, tendo em vista 
ter the conferido aferição subjetiva das justificativas para a decretação da prisão preventiva, sendo objeto de flagrante inconstitucionalidade, ainda não analisada pelo Supremo Tribunal Federal.

\subsection{CONVENIÊNCIA}

\section{INSTRUÇÃO CRIMINAL}

Deve ser utilizada quando a liberdade do réu coloca em risco a colheita de provas ou o desenvolvimento do processo.

Nucci (2014) afirma que caso o réu possa, efetivamente, ameaçar testemunhas ou destruir provas, deve-se impor a prisão preventiva; porém, havendo suspeita fundada de que a sua liberdade irrestrita pode ser meio condutor de problemas para a instrução, aplica-se a medida cautelar alternativa.

Tutela a produção de provas, impedindo que o agente destrua provas, ameace testemunhas e impeça a busca pela verdade.

\subsection{APLICAÇÃO DA LEI PENAL}

Segundo Nucci (2014, p. 84) significa garantir a finalidade útil do processo penal.
Se o acusado tem por fim não comparecer aos atos do processo, apenas para não ser reconhecido, reflete na conveniência da instrução. Se pretende fugir do País para não ser alcançado pela lei penal, insere-se neste contexto. Entretanto, pode ser dúplice o motivo, ou seja, tanto a fuga prejudica a instrução criminal, quanto a aplicação da lei penal.

Lopes (2001) ensina que essa é a prisão para evitar que o imputado fuja, tornando inócua a sentença penal por impossibilidade de aplicação da pena cominada.

O risco de fuga representa uma tutela tipicamente cautelar, pois busca resguardar a eficácia da sentença; não podendo ser presumido de nenhuma forma, devendo estar fundado em circunstâncias concretas.

\section{A INCONSTITUCIONALIDADE NA DECRETAÇÃO DA PRISÃo PREVENTIVA}

Se por um lado a aplicação da lei se encontra distorcida, por outro lado a própria lei padece de inconstitucionalidades. 


\subsection{DA GARANTIA DA ORDEM PÚBLICA}

A expressão 'garantia da ordem pública' possui um conceito vago, pois a legislação vigente não define seu conceito, deixando à cargo da doutrina e jurisprudência, que não possuem consenso.

A doutrina majoritária afirma que o conceito de garantia da ordem pública tem um caráter restritivo, entendendo que é o risco considerável de reiterações de ações delituosas por parte do réu, caso permaneça em liberdade, seja porque se trata de pessoa propensa à prática delituosa, seja porque, se solto, teria os mesmos estímulos relacionados com o delito cometido, inclusive pela possibilidade de voltar ao convívio com os parceiros do crime.

A doutrina minoritária, que parece a mais acertada, por resguardar as garantias do réu, ensina que a prisão preventiva com fundamento na garantia da ordem pública não possui caráter cautelar, possuindo um caráter de cumprimento antecipado de pena.

Nesse sentido é o ensinamento de Nicolitt (2011, p. 69):

\footnotetext{
Como reiteradamente afirmamos a prisão só é compatível com o princípio da
}

presunção de inocência quando tem por objetivo a preservação do processo, pois o contrário transforma-se em antecipação da pena. O que tutela, ou deveria tutelar, a ordem pública (prevenção geral ou específica) é a pena. Usar a prisão processual para garantir a ordem pública é antecipar os efeitos da pena, o que é inconstitucional. $\mathrm{O}$ mesmo se pode dizer em relação à ordem econômica, pois toda prisão cujo objetivo transcenda a ordem processual padece de inconstitucionalidade.

Nicolitt (2011) parece certo ao argumentar que toda prisão cujo objetivo transcenda a ordem processual padece de insconstitucionalidade, isso porque as medidas cautelares de natureza pessoal só podem ter a finalidade endoprocessual, ou seja, garantir a realização do processo. Dessa forma, utilizar a justificativa de garantia de ordem pública seria utilizá-la para proteger interesses alheios, como o de evitar a prática de outras infrações penais (finalidade extraprocessual) ofende não só a natureza da medida cautelar da prisão preventiva, como os direitos e garantias fundamentais previstos na Carta Magna.

Não se deve confundir garantia da ordem pública com "clamor público", ou muito menos com gravidade do delito ${ }^{10}$.

10 A gravidade do delito, por si só, não pode justificar a prisão preventiva, como reiteradamente vêm decidindo os tribunais superiores. Entre as 
Como já afirmado, a prisão não pode ser utilizada como "ilusão" de que o aparelho estatal funciona, pois muitas vezes ele parece não funcionar. Porém, a ideia de "justiça" culturalmente aceita, é a de que com o cumprimento de uma medida privativa de liberdade, a sociedade estará protegida criminalmente.

As medidas cautelares não existem para fazer justiça, e sim para garantir um processo de conhecimento com efetividade, calcado no garantismo penal.

Isso porque a prisão baseada em tal justificativa vem sendo utilizada como forma de prevenção geral, tendo o legislador desvirtuado o sentido e a natureza de prisão provisória.

A prevenção geral é amplamente criticada por violar o princípio da dignidade da pessoa humana, uma vez que para dar força ao Estado, utiliza-se de tal justificativa tendo como base uma pessoa, como se ela fosse mero objeto que deva ser

várias decisões, cita-se a seguinte: PRISÃO PREVENTIVA. TRÁFICO DE ENTOPERCENTES. FUNDAMENTAÇÃO. O preso em flagrante e acusado de tráfico de entorpecentes, crime de natureza hedionda, não pode ter seu pedido de liberdade provisória indeferido pela simples razão da gravidade do delito. Necessário que a manutenção da prisão seja fundamentada em fatos que indiquem sua necessidade, observados os requisitos previstos no art. 312 do CPP. Precedentes citados: RHC 11.631/MG, DJ 15/10/2001, e HC 31.230/SP, DJ 13/09/2004. (HC 39.635/DF, Rel. Min. José Arnaldo da Fonseca, julgado em 17/02/2005). exposto a todos, para primeiramente demonstrar "quão efetivo" o aparelho estatal foi ao encarcerar o acusado, e em segundo lugar, para incutir uma intimidação para que fatos de determinada natureza não ocorram novamente.

Roxin (1986, p. 24) ensina:

Como pode justificar-se que se castigue um indivíduo não em consideração a ele próprio, mas em consideração a outros? Mesmo quando seja eficaz a intimidação, é difícil compreender que possa ser justo que se imponha um mal a alguém para que outros omitam cometer um mal.

Nos dias atuais, são realizados atos de prisão arbitrários e prepotentes, justificando-se com o fundamento da garantia da ordem pública, pois o próprio CPP forneceu a liberdade para que isso fosse realizado.

Morais (2006) afirma que o art. 312 contém uma "anemia semântica", pois basta um pouco de conhecimento de estrutura linguística para construir artificialmente esses requisitos (subjetivos), cuja "falsificação" é inverificável.

A jurisprudência e a doutrina justificaram o uso da hipótese da decretação da prisão preventiva com a justificativa da garantia da ordem pública com bases em alguns fundamentos, como: 
garantir a paz social; credibilidade da justiça; periculosidade do réu; clamor público; indignação da opinião pública; repercussão do crime; garantir a integridade física do réu e seus familiares, dentre outras hipóteses.

Um dos argumentos mais utilizados, o "clamor social" é inteiramente desprovido de função cautelar e ofende os princípios constitucionais e um processo garantista, pois nesse sentido, a prisão preventiva seria decretada em virtude da gravidade abstrata do delito. Esse argumento, na verdade, é utilizado como "clamor publicado", na maioria das vezes na imprensa e canais televisivos com foco para atividades policiais. É inconcebível a utilização da justificativa, até porque o poder judiciário deve estar sujeito à obediência das leis, mormente à Constituição Federal, devendo ser afastada a utilização do Direito Penal para o agrado de maiorias, que muitas vezes são influenciadas pela mídia. Tal argumento é ainda utilizado, mesmo sendo considerado inidôneo pelo Supremo Tribunal Federal.

Outros argumentos como "garantia da paz social" também não devem ser utilizado, pois o dever de paz social é de responsabilidade da segurança pública, e não do processo penal.
Encarcerar alguém sob o argumento de credibilidade da justiça é também abominável, pois isso se faz através de políticas públicas.

E ainda, na visão de Delmanto (2001), levar alguém a prisão sob o fundamento da periculosidade, bem como sob a possibilidade deste voltar a delinquir, seria uma dupla presunção de culpabilidade.

Dessa forma, verifica-se que os argumentos para a decretação se tornam argumentos construídos pela mídia, pela sociedade, por alguns julgadores “justiceiros” e, dessa forma, há a violação de todas as garantias penais asseguradas ao acusado, se é que pode-se chamar de acusado, pois, nesse estado, já é considerado um "culpado social", pelo modo como são utilizadas as cautelares prisionais.

A prisão preventiva para garantir a ordem pública ofende o princípio da legalidade, por seu conteúdo ser indefinido, subjetivo e discricionário.

Sanguiné (2003, p. 114) é certo ao afirmar:

Quando se argumenta com razões de exemplaridade, de eficácia da prisão preventiva na luta contra a delinquência e para restabelecer o sentimento de confiança dos cidadãos no 
ordenamento jurídico, aplacar o clamor público criado pelo delito etc. que evidentemente nada tem a ver com os fins puramente cautelares e processuais que oficialmente se atribuem à instituição, na realidade, se introduzem elementos estranhos à natureza cautelar e processual que oficialmente se atribuem à instituição, questionáveis tanto desde o ponto de vista jurídico-constitucional como da perspectiva políticocriminal. Isso revela que a prisão preventiva cumpre funções reais (preventivas gerais e especiais) de pena antecipada incompatíveis com sua natureza.

Delmanto (2001, p. 183) leciona que:

A prisão preventiva se distancia de seu caráter instrumental - de tutela do bom andamento do processo e da eficácia de seu resultado ínsito a toda e qualquer medida cautelar, servindo de inaceitável instrumento de justiça sumária.

Lopes (2014, p. 617) afirma que nesse contexto, assume a prisão preventiva um caráter de pena antecipada, violando o devido processo legal e a presunção de inocência.

\subsection{DA GARANTIA DA ORDEM ECONÔMICA}

Esse fundamento tutela as condutas que trazem desarmonia da ordem econômica, pois ameaçam o sistema financeiro ou ações e valores.

É parecido com a justificativa para a garantia da ordem pública, mas no presente fundamento, são trazidos à baila argumentos econômicos.

O objetivo aqui é preservar o sistema financeiro. O Direito Penal como ultima ratio não deve ter o condão de tutelar o direito como se Direito Administrativo fosse, ainda mais utilizando-se da prisão preventiva.

Útil para tanto seria o sequestro e a indisponibilidade de bens (OLIVEIRA, 2008, p. 519), pois assim diminuiria as perdas econômicas e tutelaria a ordem financeira. Até porque, a decretação de prisão preventiva para o agente que pratica um crime econômico, é ineficaz, pois não impede a reiteração da conduta, tendo em vista não ser compatível com o crime em comento.

Verifica-se que as prisões para a garantia da ordem pública e para a garantia da ordem econômica são inconstitucionais, pois não são cautelares e não tutelam o 
processo de conhecimento, além de ambas possuírem um conceito vago e sujeito à atuações ex officio subjetivas pelo magistrado. Tais justificavas são, portanto, medidas de segurança pública, não podendo realizar uma expansão ilegal das medidas cautelares excepcionais.

\section{CONSIDERAÇÕES FINAIS}

Ferrajoli (2014) vem demonstrando há anos como deve se pautar um processo calcado em garantias penaisconstitucionais.

Por meio de orientações e baseado em ensinamentos iluministas, Ferrajoli (2014) afirma que um processo só é justo quando nas decisões judiciais há um magistrado garantista.

No cenário das decisões judiciais é que surge o problema da decretação da prisão preventiva, que a cada dia mais está sendo banalizada no cenário jurídico, transformando em regra o que deveria ser exceção.

Há um esquecimento dos princípios constitucionalmente garantidos, bem como do princípio da fragmentariedade do direito penal, pois a prisão preventiva - que é medida cautelar - tem se tornado regra. Prende-se para depois investigar.

Os meios de comunicação e a massa conservadora incentivam tal decisão, criando uma "falsa justiça" cada vez que um indivíduo é preso cautelarmente.

Como se não bastasse, além de ser decretada a prisão preventiva como medida primeira, muitos julgadores utilizam fundamentos genéricos e em algumas vezes inconstitucionais para a decretação da mesma, como a garantia da ordem pública e a garantia da ordem econômica, que são medidas de segurança, e não cautelares, por não servirem ao processo de conhecimento.

Diante de todos esses problemas, vê-se o acusado tratado como mero objeto processual, e não como ser humano. Clama a sociedade por um processo justo, com preservação de garantias, e isso não é difícil de se alcançar.

Ferrajoli (2014) propõe um modelo garantista a ser seguido, um modelo que devia ser regra, e não opção.

A prisão preventiva vem assumindo caráter de pena antecipada, e cabe aos operadores do Direito mudar essa realidade. 
A utilização dos princípios constitucionais, mormente dos ensinamentos garantistas traz à sociedade uma segurança jurídica real, e não falaciosa, como a que é mostrada hoje.

\section{REFERÊNCIAS}

BADARÓ, Gustavo Henrique e LOPES JR., Aury. Direito ao Processo Penal no Prazo Razoável. Rio de Janeiro: Lumen Juris, 2006.

BECCARIA, Cesare. Dei delliti e delle pene. A cura de Franco Venturi. Torino: Einaudi, 2008.

Dos delitos e das penas. São

Paulo: Martins Fontes, 1991.

BRASIL. Código Penal. DECRETO-LEI $\mathbf{N}^{\mathbf{0}} \mathbf{2 . 8 4 8} / 40$. Disponível em: <http:// http://www.planalto.gov.br/ccivil 03/decre to-lei/del2848.htm $>$. Acesso em 04/03/2015.

BRASIL. Código Penal. DECRETO-LEI No 3.689/41. Disponível em: <http:// http://www.planalto.gov.br/ccivil_03/decre to-lei/Del3689.htm>. Acesso em 04/03/2015.

BRASIL. Constituição da República Federativa do Brasil de 1988. Disponível em:

<http://www.planalto.gov.br/ccivil_03/con stituicao/constituicaocompilado.htm>.

Acesso em: 06/02/2015.

CADEMARTORI, Sergio. Estado de

Direito e Legitimidade: Uma

Abordagem Garantista. Porto Alegre:

Livraria do Advogado, 1999.
CARNELUTTI, Francesco. Lecciones sobre el Proceso Penal. Trad. Santiago Santís Melendo. Buenos Aires: Bosch 1950.

CARVALHO, Salo de. Pena e garantias. Rio de Janeiro: Editora Lumen Juris, 2008.

DELMANTO JÚNIOR, Roberto. As modalidades de prisão provisória e seu prazo de duração. Rio de Janeiro: Renovar, 2001.

FERRAJOLI, Luigi. Direito e Razão: Teoria do Garantismo Penal. São Paulo: Revista dos Tribunais, 2014.

FILANGIERI, G. La Scienza della legislazione 1780-1791. Napoli: Grimaldi, 2003.

GRECO, Rogério. Curso de Direito Penal.Parte Geral. Volume 1. Rio de Janeiro: Impetus, 2006.

IPPOLITO, D. Mario Pagano: Il pensiero giuspolitico di un illuminista. Torino: Giappichelli, 2008.

LIMA, Renato Brasileiro de. Manual de Processo Penal. Bahia: Juspodvm, 2014.

LOPES JÚNIOR, Aury. Direito Processual Penal. São Paulo: Saraiva, 2014.

MORAIS DA ROSA, Alexandre. Decisão Penal: a bricolage de significantes, Rio de Janeiro: Lumen Juris, 2006.

NICOLITT, André Luiz. Lei N ${ }^{\circ}$ 12.403/2011 - o Novo Processo Penal Cautelar - a Prisão e As Demais Medidas Cautelares, Rio de Janeiro: Elsevier Campus, 2011. 
NUCCI, Guilherme de Souza. Código de Processo Penal Comentado. Rio de Janeiro: Forense, 2014.

PACELLI DE OLIVEIRA, Eugênio. Curso de Processo Penal. Rio de Janeiro: Lumen Juris, 2008.

ROXIN, Claus. Problemas Fundamentais de Direito Penal. Lisboa: Vega, 1986.

SANGUINÉ, Odone. A Inconstitucionalidade do Clamor
Público como Fundamento da Prisão Preventiva. Revista de Estudos Criminais. Porto Alegre, Nota Dez, n. 10, p. 114.

TÁVORA, Nestor. Código de Processo Penal para concursos. Bahia: Juspodvm, 2014.

ZAFFARONI, Eugenio Raúl. Em busca das penas perdidas: a perda da legitimidade do sistema penal. Rio de Janeiro: Revan, 2001. 